\title{
EFFECT OF YOGHURT PILLARED WITH PROPOLIS ON HYPERGLYCEMIC RATS
}

\author{
Hassan M. Bukhari ${ }^{1}$, Abdelghany H. Abdelghany ${ }^{2,3}$, Ibrahim Saad Nada ${ }^{3,4}$ and Eslam A. \\ Header ${ }^{1,5}$ \\ ${ }^{1}$ Clinical Nutrition Department, Faculty of Applied Medical Sciences, Umm al Qura University \\ Makkah, Saudi Arabia, ${ }^{2}$ Department of Anatomy and Embryology Faculty of Medicine, Alexandria \\ University, Egypt, ${ }^{3}$ Laboratory Department, Faculty of Applied Medical Sciences, Umm al Qura \\ University, Makkah, Saudi Arabia, ${ }^{4}$ Community Medicine Department, Faculty of Medicine, Al Azhar \\ University. ${ }^{5}$ Nutrition and Food Science Department, Faculty of Home Economics Minufiya \\ University, Egypt. \\ Corresponding Author: Hassan M. Bukhari, Department of Clinical Nutrition, Faculty of Applied \\ Medical Sciences, Umm Al-Qura University, Makkah, Saudi Arabia, P.O. Box: 715 \\ hmyb2000@yahoo.com
}

\begin{abstract}
Dietary supplementation of yoghurt with plants rich in antioxidants such as propolis which is an adhesive resinous material collected by honey bees is recently recommended. This study aimed at investigating the protective effect against the hyperglycemia and hyperlipidemia. The study showed that yoghurt with propolis had a hypoglycemic effect together with reduction of the serum levels of cholesterol, low density and very low density lipoproteins with elevation of high density lipoproteins. The atherosclerosis indices were affected with reduction of low density lipoproteins-cholesterol/high density lipoproteinscholesterol and elevation of the high density lipoprotein-cholesterol/total cholesterol. This was attributed to the reduction of glucose absorption and inhibition of $\alpha$-glucosidase together with the antioxidant activity with regain of the pancreatic $\beta$-cell function. The hypolipidemic effect and consequently protective effect against atherosclerosis was attributed to the binding, breakdown and reduction of absorption of cholesterol together with the antioxidant activity of both yoghurt and propolis. Down regulation of the expression of the angiogenic gene factors which have a role in the pathogenesis of atherosclerosis may play a role.

Thus, this dietary supplementation may be manufactured and used for its value in reducing hyperglycemia and hyperlipidemia in cases of diabetes mellitus.
\end{abstract}

Keywords: yoghurt, propolis, diabetes mellitus, atherosclerosis, hyperglycemia, hyperlipedemia, cholesterol, lipoproteins antioxidants.

\section{INTRODUCTION}

Yogurt is defined by the Codex Alimentarius of 1992 as a coagulated milk product that results from fermentation of lactic acid in milk by Lactobacillus bulgaricus and Streptococcus thermophilus

(Bourlioux and Pochart, 1988).

Many investigators have studied the therapeutic and preventive effects of yogurt and lactic acid bacteria, which are commonly used in yoghurt production, on 
diseases such as cancer, infections, gastrointestinal disorders, and asthma (Cano et al., $2002 \&$ Simin and WoelKyu, 2000). Moreover, many studies provide a strong rationale for the hypothesis that increased yoghurt consumption may enhance the immune response particularly in immunocompromised populations (Simin and Woel-Kyu, 2000). Some researchers mentioned the beneficial effect of yoghurt on the elevated blood glucose level and the preventive effect on the development of diabetic complications (Bijyoet et al., 1996 \& Lee and De Boer, 1994).

In recent years, it has been shown that dietary supplementation with medicinal plants rich in natural antioxidants such as vitamins $\mathrm{C}$ and $\mathrm{E}$, phenolics and flavonoids attenuated the oxidative stress and diabetic states (Shori and Baba, 2011).

Propolis is an adhesive resinous material collected by honey bees from plants and certain plant sources neighboring their hives. The worker bees apply the resin to seal any cracks and fissures in the hive and they line their front door with it to prevent contamination (ElKott and Owayss, 2008 \& El-Sayed et al., 2009). The chemical consistency of propolis contains at least 200 compounds that include fatty and phenolic acids, phenolic esters and flavonoids (Marcucci et al., 1996 \& Bhadauria, 2011).

Diabetes mellitus is a metabolic disorder of multiple aetiology characterized by hyperglycemia with disturbances of the fat profile and protein metabolism resulting from defects in insulin secretion or insulin action or both. Hyperglycemia is accused as the main factor to cause diabetes chronic complications (Yajing et al., 2012). Diabetes can be produced in animals by drugs as alloxan and Streptozotocin (STZ) (Oberley, 1988).

Cardiovascular diseases as atherosclerosis and coronary heart diseases are the most common causes of mortalities in most countries. Hypercholesterolemia is among the remarkable aggravating factors (Baroutkoub, 2010 \& Pan and Zhang, 2008). According to the reported studies, the prevalence rate of hypercholesterolemia among individuals over 15 years of age is $11 \%$ (Bruckert, 2006).

Numerous drugs that lower the cholesterol level have been used but there were many undesirable side effects. Thus, dietary therapy and food intervention are among the recommended treatments (Baroutkoub, 2010 \& Bruckert, 2006).

Many studies have been performed in experimental animals and humans to elucidate the effect of fermented dairy products on serum cholesterol (St-Onge et al., 2000).

Thus, the present study was designed to investigate the probable antidiabetic and hypolipidemic effects of yoghurt with propolis in STZ-induced diabetic rats.

\section{MATERIALS AND METHODS}

\section{1-Materials:}

A- Rats: Thirty-six rats (Male SpragueDawley) of 12 wk old were purchased from Helwan experimental animal station. All rats were housed individually in wellaerated cages and fed on basal diet for one week for adaptation, in animal house of Nutrition and Food Sciences department, Faculty of Home Economics, Minufiya University. The rats were divided into two groups (18 normal and 18 diabetic rats).

B- Basal Diet: The basal diet consists of casein $(12.5 \%)$, corn oil (10\%), choline chloride $(0.2 \%)$, vitamin mixture $(1 \%)$, cellulose $(5 \%)$, salt mixture $(4 \%)$, sucrose 
(22\%) and corn starch (up to 100\%), (Campbell, 1963 \& (Hegested, 1941).

C- Bee propolis: honey bee propolis will be purchased from local farm of bee in ElDakhlia Governorate of Egypt.

d- Yoghurt: yoghurt pillared with $(10 \%$ and 25\%) propolis (YPWP) were made in Nutrition and Food Science Department, Faculty of Home Economics Minufiya University.

e- Streptozotocin (STZ): Diabetes was induced in one group (18 rats) via intraperitoneal injection of by $65 \mathrm{mg} / \mathrm{kg}$ of streptozotocin (STZ) administered i.p. in citrate buffer ( $\mathrm{pH} 4.2) 10 \mathrm{~m}$ molar or fresh saline (Krishnakumar et al., 1999). After 7 days blood glucose levels were measured to confirm the induction of diabetes. Rats with glucose level above $200 \mathrm{mg} / \mathrm{dl}$ were selected as diabetic rats and were included in the experiment.

\section{2-Methods:}

a- Experimental Design: the two groups of rats were fed on basal diet $+10 \%$ of yoghurt pillared with $10 \%$ and $20 \%$ propolis. The diet was fed and water was provided for the experimental period.

Each group (18 rats) was divided into 3 subgroups. So, there were 6 groups:

1- Control negative: represent the normal rats fed on basal diet.

2- Normal rats fed on basal diet $+10 \%$ of yoghurt pillared with $10 \%$ propolis.

3- Normal rats fed on basal diet $+10 \%$ of yoghurt pillared with $25 \%$ propolis.

4- Control positive: represent the diabetic rats fed on basal diet.

5- Diabetic rats fed on basal diet $+10 \%$ of yoghurt pillared with $10 \%$ propolis.

6- Diabetic rats fed on basal diet $+10 \%$ of yoghurt pillared with $25 \%$ propolis.

During the experimental period (6 weeks), the diet consumed was recorded every day; body weight was recorded every week.

\section{b. Biochemical study:}

At the end of the experimental period, rats were fasted overnight before sacrificing. Blood samples were collected from the abdominal aorta, placed in sterile tubes, and centrifuged at $3000 \mathrm{rpm}$ for 15 minutes at $4^{\circ} \mathrm{C}$. The obtained serum samples were analyzed for:

1- Blood glucose test according to the method of Trinder (1969).

2- Total cholesterol test according to Allain, (1974).

3- High-density lipoprotein (HDL) cholesterol test according to the method of Fnedewaid (1972) \& Gordon and Amer (1977), triglycerides test Young and Pestaner (1975).

4- Very low density lipoprotein (VLDL) and low density lipoprotein (LDL) will be carried out according to the method of Lee and Nieman (1996) as follows: very low density lipoprotein $(\mathrm{VLDL}=$ triglycerides 15) and LDL $=($ Total cholesterol - high density lipoprotein (HDL) - VLDL).

\section{c- Statistical Analysis:}

The obtained data will be presented as the mean and standard deviation, Dunnett's t-test for multicomparison will be applied to determine the statistical significance of the difference between the two groups in the animal study, using the (SPSS, 2008).

\section{RESULTS}

\section{A- The effect of Streptozotocin (STZ):}

Streptozotocin-induced diabetes rats showed the following results:

1- The blood glucose level was elevated up to $203.8 \pm 1.1$ compared to $85.1 \pm 4.2$ $\mathrm{mg} / \mathrm{dl}$ in control negative rats.

2- The serum cholesterol level was elevated up to $130.8 \pm 8.4$ compared to $83.6 \pm 4.3 \mathrm{mg} / \mathrm{dl}$ in control negative rats.

3- The serum triglycerides level was elevated up to $141.3 \pm 9.9$ compared to $91.3 \pm 4.6 \mathrm{mg} / \mathrm{dl}$ in control negative rats. 
4- The serum level of high density lipoproteins was reduced to $25.8 \pm 1.6$ compared to $35.7 \pm 2.2 \mathrm{mg} / \mathrm{dl}$ in control negative rats.

5- The serum level of low density lipoproteins was elevated up to $76.74 \pm 2.5$ compared to $29.64 \pm 3 \mathrm{mg} / \mathrm{dl}$ in control negative rats.

6- The serum level of very low density lipoproteins was elevated up to $28.26 \pm 1.9$ compared to $18.26 \pm 2 \mathrm{mg} / \mathrm{dl}$ in control negative rats.

7- The LDLc/HDLc was elevated up to $2.97 \pm 0.5$ compared to $0.82 \pm 0.02$ in control negative rats.

8- The HDLc/TC\% was reduced to $19.7 \pm 2.3$ compared to $42.7 \pm 2.7$ in control negative rats.

\section{B- The effect of yogourt pillared with propolis (YPWP):}

1- The effect of (YPWP) on blood glucose level: (Table 1)

In the control negative rats, the blood glucose level was reduced from 85.1 \pm 4.2 to $84.2 \pm 5.1$ and $81.8 \pm 3.2 \mathrm{mg} / \mathrm{dl}$ in the rats fed with yoghurt pillared with $10 \%$ propolis and $25 \%$ propolis respectively. The reduction was not statistically significant.

In the diabetic rats, the level was reduced from $203.8 \pm 1.1$ in the control positive group to $146 \pm 8.16$ and $121 \pm 1.46 \mathrm{mg} / \mathrm{dl}$ in the rats fed with yoghurt pillared with $10 \%$ propolis and $25 \%$ propolis respectively. The reduction was statistically significant.

\section{2- The effect of (YPWP) on the lipid} profile: (Table 2)

A. The effect of (YPWP) on the serum cholesterol level:

It was reduced from $83.6 \pm 4.3$ in the control negative rats to $78.4 \pm 3.8$ and $75.4 \pm 3.5 \mathrm{mg} / \mathrm{dl}$ in rats fed with yoghurt with $10 \%$ and $25 \%$ propolis respectively.
The decrease was statistically significant in the $25 \%$ propolis group.

In the diabetic rats, the level was reduced from $130.8 \pm 8.4$ in the control positive rats to $118.3 \pm 8$ and $104.7 \pm 6$ $\mathrm{mg} / \mathrm{dl}$ in rats fed on yoghurt with $10 \%$ and $25 \%$ propolis. The decrease was statistically significant in the $10 \%$ and $25 \%$ propolis groups.

B. The effect of (YPWP) on the serum triglycerides level:

The level was decreased from $91.3 \pm 4.6$ in the control negative rats to $87.4 \pm 5.2$ and $85.9 \pm 9.3 \mathrm{mg} / \mathrm{dl}$ in rats fed on yoghurt with $10 \%$ and $25 \%$ propolis respectively. The decrease was not statistically significant.

In the diabetic rats, the level was reduced from $141.3 \pm 9.9$ in the control positive rats to $134.3 \pm 9.2$ and $125.2 \pm 5.9$ $\mathrm{mg} / \mathrm{dl}$ in rats fed on yoghurt with $10 \%$ and $25 \%$ propolis respectively. The decrease was statistically significant in the $25 \%$ propolis group.

C. The effect of (YPWP) on the serum level of high density lipoproteins:

It was elevated from $35.7 \pm 2.2$ in the control negative rats to $36.8 \pm 1.8$ and $38.1 \pm 2.3 \mathrm{mg} / \mathrm{dl}$ in rats fed on yoghurt with $10 \%$ and $25 \%$ propolis respectively. The increase was not statistically significant.

In the diabetic rats, the level increased from $25.8 \pm 1.6$ in the control positive rats to $29.3 \pm 1.1$ and $33 \pm 1.7$ in rats fed on yoghurt with $10 \%$ and $25 \%$ propolis respectively. The increase was statistically significant in $25 \%$ propolis group.

\section{The effect of (YPWP) on the serum level of low density lipoproteins:}

It was reduced from $29.64 \pm 3$ in the control negative rats to $24.1 \pm 2.4$ and $20.12 \pm 2.5 \mathrm{mg} / \mathrm{dl}$ in the rats fed on yoghurt with $10 \%$ and $25 \%$ propolis respectively. 
The decrease was statistically significant in both groups.

In the diabetic rats, the level decreased from $76.74 \pm 2.5$ in the control positive rats to $62.14 \pm 1.8$ and $46.7 \pm 5.2$ $\mathrm{mg} / \mathrm{dl}$ in the rats fed on yoghurt with $10 \%$ and $25 \%$ propolis respectively. The decrease was statistically significant in the $25 \%$ propolis group.

E. The effect of (YPWP) on the serum level of very low density lipoproteins:

It was reduced from $18.26 \pm 2$ in the control negative rats to $17.5 \pm 1.7$ and $17.18 \pm 3.8 \mathrm{mg} / \mathrm{dl}$ in rats fed with yoghurt with $10 \%$ and $25 \%$ propolis respectively. The reduction was not statistically significant.

In the diabetic rats, the very low density lipoproteins were decreased from $28.26 \pm 1.9$ in the control positive rats to $26.86 \pm 9.3$ and $25 \pm 2.3 \mathrm{mg} / \mathrm{dl}$ in the rats fed with yoghurt with $10 \%$ propolis and $25 \%$ propolis respectively. The decrease was not statistically significant.

3- The effect of (YPWP) on atherosclerosis indices: (table 3)

Regarding LDL-C/HDL-C, it was reduced $0.82 \pm 0.02$ in the control negative rats to $0.65 \pm 0.02$ and $0.53 \pm 0.01$ in the rats fed on yoghurt pillared with $10 \%$ and $25 \%$ propolis respectively. The reduction was statistically significant.

In the diabetic rats, the level was reduced from $2.97 \pm 0.5$ in the control positive rats to $2.13 \pm 0.2$ and $1.4 \pm 0.1$ in the rats fed on yoghurt pillared with $10 \%$ and $25 \%$ propolis respectively. The reduction was statistically significant with the $25 \%$ propolis group.

Regarding HDL-C/TC\%, the normal rats showed elevation from $42.7 \pm 2.7$ in the control negative rats to $46.9 \pm 2.7$ and $50.5 \pm 1.1$ in the rats fed on yoghurt pillared with $10 \%$ and $25 \%$ propolis respectively. The difference was statistically significant with the $25 \%$ propolis group.

In the diabetic rats, it was elevated from $19.7 \pm 2.3$ in the control positive rats to $24.8 \pm 2.7$ and $31.5 \pm 0.6$ in the rats fed on yoghurt pillared with $10 \%$ and $25 \%$ propolis respectively. The difference was statistically significant in both groups.

\section{DISCUSSION}

The modern technology of supplementing diet with herbal medicinal components has been increased to avoid the side effects of medicines in cases of immunocompromised individuals and some diseases as diabetes mellitus (Shori and Baba, 2011). Diabetes may be induces in experimental animals by certain drugs as STZ and alloxan (Oberley, 1988).

Regarding the effect of STZ on the blood glucose level, the present study showed that STZ induced diabetes mellitus with elevated blood glucose level.

STZ is an alkylating agent that experimentally produces diabetes due to beta cell death by DNA damage (Yang and Wright, 2002). In diabetes, insulin signaling breaks down preventing the cells from absorbing sugar. Thus, the cells resort to other methods of energy production that are more likely to produce free radicals and reactive oxygen species (ROS) which are mediators of diabetes complications (Bhadauria, 2011 \& Vitaglione et al., 2004).

These free radicals initiate peroxidation of the fatty acids of cell membrane and damage of DNA and cell proteins that constitute enzymes. However, a condition of oxidative stress establishes due to decreased activity of antioxidant enzymes and insufficient defense capacities against ROS with the 
progression of pancreatic beta-cell dysfunction (Kajimoto and Kaneto, 2004 \& Oberley, 1988).

El-Sayed et al. (2009) mentioned that there is marked elevation in pancreatic tissue content of MDA as well as serum NO level with significant reduction in the antioxidant parameters as GSH in STZinduced diabetic rats.

GSH is considered the first line of defense against free radicals and it could be found in every cell of the body adding to their protection. GSH is a powerful combination of three amino acids, Lcysteine, L-glutamic acid and glycine. These three amino acids when combined produce the most powerful antioxidant known (Bhadauria, 2011).

It was mentioned that antioxidants can help prevent complications of diabetes by converting the free radicals and ROS into non toxic compounds (Bankova et al., 1995 \& Oberley, 1988).

The present study showed that treatment with yoghurt pillared with propolis resulted in reduction of the blood glucose level in diabetic rats.

Shori and Baba, (2011) and Kim et al. (2005) proved the hypoglycemic effect of yoghurt. This was attributed to its inhibitory effect on $\alpha$-glucosidase in milk. This enzyme is essential to enhance glucose absorption. Thus, fermented milk products as yoghurt through this inhibitory effect may decrease glucose absorption and reduce hyperglycemia (Bijyoet $\boldsymbol{e t}$ al., 1996 \& Ramchandran and Shah, 2008). Another mechanism is that yoghurt formation and milk fermentation increase the antioxidant activities and the defense capacities against ROS with the regain of pancreatic beta-cell function (Shori and Baba, 2011 \& Kajimoto and Kaeto, 2004).

Regarding propolis, Abo-Salem $\boldsymbol{e t}$ al. (2009), El-Sayed et al. (2009),
Bhadauria, (2011) and Matusi et al. (2004) reported that propolis had a hypoglycemic effect.

Giugliano et al. (2008) reported that islet dysfunction and peripheral insulin resistance are both present in diabetes mellitus and are both necessary for the development of hyperglycemia (Giugliano et al., 2008). Propolis could be effective in reducing hyperglycemia through preventing the development of insulin resistance and improving insulin sensitivity (Zamami et al., 2010). Another role mentioned by El-Sayed $\boldsymbol{e t}$ al., (2009) is the antioxidant activity of propolis by increasing the GSH level and reduction of the pancreatic tissue content of MDA with amendment of the beta-cells capacity.

Regarding the effect of STZ on the lipid profile, the present study showed that STZ induced diabetes mellitus with elevated serum levels of cholesterol, triglycerides, LDL and VLDL while the serum level of HDL was reduced. Moreover, the LDL-C/HDL-C was elevated and the HDL-C/TC was reduced. This brings about the risk of cardiovascular diseases as atherosclerosis.

Cholesterol is transported in the plasma by specific lipoproteins. In healthy individuals, about thirty percent of blood cholesterol is carried by HDL. Low density lipoprotein cholesterol (LDL-C) is the serum cholesterol carried on low density lipoproteins. It represents approximately 60 to 70 per cent of the total cholesterol (Toth, 2005 \& Rosenson et al., 2002).

HDL particles are able to remove cholesterol from within artery atheroma and transport it back to the liver for excretion or re-utilization, which is the main reason why the cholesterol carried within HDL particles (HDL-cholesterol) is sometimes called good cholesterol. It also 
scavenges and removes LDL-C or the bad cholesterol (Kwiterovich, 2000).

Therefore, those with higher levels of HDL-C seem to have fewer problems with cardiovascular diseases as atherosclerosis than those with low HDLC.

The more small dense LDL particles lead to a higher risk factor for atherosclerosis than do the larger particles of HDL This is because the smaller particles are more easily able to penetrate the endothelium lining the blood vessels as most LDL particles are very close in size to the normal gaps in the endothelium. Thus, LDL particles also transport cholesterol into the arterial wall where they are retained and start the formation of atheromatous plaques with proliferation of the vascular endothelial cells. Over time vulnerable plaques rupture, activate blood clotting and produce arterial stenosis (Rosenson et al., 2002).

Moreover, the protein and lipid constituents of HDL help to maintain the endothelium of the blood vessels and help to inhibit oxidation, inflammation, activation of the endothelium, coagulation, and platelet aggregation. All these properties may contribute to the ability of HDL to protect from atherosclerosis, as the endothelial damage is the first step in the process of atherosclerosis (Toth, 2005 \& Kwitervich et al., 2000).

The present study showed that consumption of yoghurt pillared with propolis reversed the effects of STZ by reducing the serum levels of cholesterol, triglycerides, LDL and VLDL while increasing the serum level of HDL with improvement of the LDL-C/HDL-C and HDL-C/TC and therefore, reducing the risk for atherosclerosis.

This agrees with Ejtahed $\boldsymbol{e t}$ al. (2011-a) who found that yoghurt consumption in cases of type 2 diabetes caused a decrease in total cholesterol and LDL-cholesterol. The total cholesterol:HDL-cholesterol ratio and LDL-cholesterol: HDL-cholesterol ratio as atherogenic indices significantly decreased with yoghurt consumption (Ejtahed $\boldsymbol{e t}$ al., 2011-b).

Similar results were obtained by Sadrzadeh-Yeganeh et al. (2010), Kiessling et al. (2002) and Ataie-Jafari et al. (2009) who found a decrease in total cholesterol: HDL-cholesterol ratio and an increase in HDL-cholesterol and an increase in the serum level of HDLcholesterol with improvement of LDLC:HDL-C ratio

The mechanism of serum lipid improvement have been suggested as the lactic acid bacteria inhibit exogenous cholesterol absorption from the intestine by binding and direct breakdown of cholesterol (Begley et al., 2006).

Another mechanism is deconjugation of bile acids. Bile plays an essential role in fat digestion. Bile salts are synthesized mainly from cholesterol and conjugated with proteins (Begley $\boldsymbol{e t}$ al., 2006 \& Batta et al., 1990).

Deconjugated or free bile acids are excreted more rapidly from the intestinal tract than are conjugated bile salts. Thus, the synthesis of new bile salts from cholesterol can reduce the total cholesterol concentration in the body. The enzyme responsible for the deconjugation activity is bile salt hydrolase. Lactic acid bacteria stimulate the activity of bile salt hydrolase (Begley et al., 2006 \& Batta et al., 1990). Propolis has a beneficial effect in diminishing the risk of cardiovascular diseases. Yu et al. (2011), El-sayed et al. (2009) and Kolankaya et al. (2002) found that the extracts of propolis are beneficial in increasing HDL-C and decreasing the levels of LDL-C and triglycerides. 
Vascular smooth muscle cells are critically involved in the onset of atherosclerosis. The caffeic acid phenethyl ester; one of the main constituents of honeybee propolis, has an antiproliferative effect by interfering with cell cycle progression leading to growth arrest (Roos et al., 2011).

Daleprane et al. (2011) found that Propolis improved plasma lipids and reduced the atheromatous lesion areas by modulating and down regulating the expression of the angiogenic gene factors which have a role in the pathogenesis of atherosclerosis; VCAM, MCP-1, FGF, PDGF, VEGF, PECAM and MMP-9.

Free radicals and reactive oxygen species have been implicated in the pathogenesis and complications of degenerative diseases as diabetes mellitus and atherosclerosis (El-sayed $\boldsymbol{e t}$ al., 2009 \& Mercury et al., 2000). There will be disruption of cellular functions with oxidative damage to the endothelial cell membranes with enhancement of their susceptibility to lipid peroxidation. These may have a role in endothelial dysfunction and inflammation (Cam et al., 2003 \& Kajimoto and kaneto, 2004).

Propolis reactivated the antioxidant enzymes and restored GSH level, which in turn increased the detoxification of active metabolites of STZ and ROS. Flavonoids and their esters are the pharmacologically active molecules of propolis and have been hypothesized to influence the antioxidant activity of propolis. At least 38 flavanoids have been found in propolis (Bhadauria, 2011\& Bankova et al., 1995). Propolis also is proved to inhibit the generation of thiobarbituric acid which is a marker of lipid peroxidation indicating a cell membrane stabilizing effect probably by scavenging free radicals and reversal of peroxidation of the fatty acids (Bhadauria, 2011\& Liu et al., 2004).

\section{CONCLUSION}

This study proved that yoghurt pillared with propolis constitutes a diet that could be manufactured and offers a promising therapeutic value regarding the hyperglycemic and dyslipidemic effects in cases of diabetes. Further studies are recommended to study this effect on humans and to get this product manufactured and distributed on a wide scale.

Table (1): Effects of (YPWP) on blood glucose (mg/dl): 


\begin{tabular}{|c|c|c|c|c|c|c|}
\hline \multirow{3}{*}{$\begin{array}{l}\text { Groups } \\
\text { Serum } \\
\text { glucose }\end{array}$} & \multicolumn{3}{|c|}{ Normal Rats } & \multicolumn{3}{|c|}{ Hyperglycemic Rats } \\
\hline & \multirow{2}{*}{$\begin{array}{c}\text { Control } \\
(-)\end{array}$} & \multicolumn{2}{|c|}{ Yoghurt with bee propolis } & \multirow{2}{*}{$\begin{array}{l}\text { Control } \\
(+)\end{array}$} & \multicolumn{2}{|c|}{$\begin{array}{l}\text { Yoghurt with bee } \\
\text { propolis }\end{array}$} \\
\hline & & $10 \%$ & $25 \%$ & & $10 \%$ & $25 \%$ \\
\hline Mean & 85.1 & 84.2 & 81.8 & 203.8 & 146 & 121 \\
\hline SD & 4.2 & 5.1 & 3.2 & 11 & 8.6 & 14.6 \\
\hline Sig & & $\mathrm{NS}$ & NS & & $*$ & $* *$ \\
\hline
\end{tabular}

*Differences are significant at 5\% $(\mathrm{P}<0.05)$.

**Differences are significant at $1 \%(\mathrm{P}<0.01)$.

*** Differences are significant at $0.1 \%(\mathrm{P}<0.001)$.

Table (2): Effects of (YPWP) on lipids profiles (mg/dl):

\begin{tabular}{|c|c|c|c|c|c|c|}
\hline \multirow{2}{*}{$\begin{array}{c}\text { Groups } \\
\text { Variables }\end{array}$} & \multicolumn{3}{|c|}{$\begin{array}{c}\text { Normal } \\
\text { Control }\end{array}$} & \multicolumn{2}{|c|}{$\begin{array}{c}\text { Yoghurt with bee } \\
\text { propolis }\end{array}$} & \multicolumn{3}{|c|}{$\begin{array}{c}\text { Control } \\
(-)\end{array}$} & \multicolumn{1}{|c|}{$\begin{array}{c}\text { Yoghurt with bee } \\
\text { propolis }\end{array}$} \\
\cline { 3 - 4 } \cline { 7 - 8 } & & $\mathbf{1 0 \%}$ & $\mathbf{2 5 \%}$ & & $\mathbf{1 0 \%}$ & $\mathbf{2 5 \%}$ \\
\hline Cholesterol & $83.6 \pm 4.3$ & $78.4 \pm 3.8$ & $75.4 \pm 3.5^{*}$ & $130.8 \pm 8.4$ & $118.3 \pm 8^{*}$ & $104.7 \pm 6^{* *}$ \\
\hline Triglyceride & $91.3 \pm 4.6$ & $87.4 \pm 5.2$ & $85.9 \pm 9.3$ & $141.3 \pm 9.9$ & $134.3 \pm 9.2$ & $125 \pm 25.9^{*}$ \\
\hline HDLc & $35.7 \pm 2.2$ & $36.8 \pm 1.8$ & $38.1 \pm 2.3$ & $25.8 \pm 1.6$ & $29.3 \pm 1.1$ & $33 \pm 1.7^{*}$ \\
\hline LDLc & $29.64 \pm 3$ & $24.1 \pm 2.4^{*}$ & $20.12 \pm 2.5^{*}$ & $76.74 \pm 2.5$ & $62.14 \pm 1.8$ & $46.7 \pm 5.2^{* *}$ \\
\hline VLDLc & $18.26 \pm 2$ & $17.5 \pm 1.7$ & $17.18 \pm 3.8$ & $28.26 \pm 1.9$ & $26.86 \pm 9.3$ & $25 \pm 2.3$ \\
\hline
\end{tabular}

*Differences are significant at 5\% $(\mathrm{P}<0.05)$.

$* * *$ Differences are significant at $0.1 \%(\mathrm{P}<0.001)$.

Table (3): Atherogenesity indices for control positive and different groups of rats fed on (YPWP):

\begin{tabular}{|c|c|c|c|c|c|c|}
\hline \multirow{3}{*}{$\begin{array}{l}\text { Groups } \\
\text { Variables }\end{array}$} & \multicolumn{3}{|c|}{ Normal } & \multicolumn{3}{|c|}{ Hyperglycemic } \\
\hline & \multirow{2}{*}{$\begin{array}{l}\text { Control } \\
(-)\end{array}$} & \multicolumn{2}{|c|}{$\begin{array}{c}\text { Yoghurt with bee } \\
\text { propolis }\end{array}$} & \multirow{2}{*}{$\begin{array}{c}\text { Control } \\
(+)\end{array}$} & \multicolumn{2}{|c|}{$\begin{array}{c}\text { Yoghurt with bee } \\
\text { propolis }\end{array}$} \\
\hline & & $10 \%$ & $25 \%$ & & $10 \%$ & $25 \%$ \\
\hline LDLc/HDLc & $0.82 \pm 0.02$ & $0.65 \pm 0.02^{*}$ & $0.53 \pm 0.01^{*}$ & $2.97 \pm 0.5$ & $2.13 \pm 0.2$ & $1.4 \pm 0.1^{\text {** }}$ \\
\hline HDLc/TC\% & $42.7 \pm 2.7$ & $46.9 \pm 2.7$ & $50.5 \pm 1.1^{*}$ & $19.7 \pm 2.3$ & $24.8 \pm 2.7^{*}$ & $31.5 \pm 0.6^{* * *}$ \\
\hline
\end{tabular}

$*$ Differences are significant at $5 \%(\mathrm{P}<0.05) . \quad * *$ Differences are significant at $1 \%(\mathrm{P}<0.01)$.

$* * *$ Differences are significant at $0.1 \%(\mathrm{P}<0.001)$.

\section{REFERENCES}


Abo-Salem OM, El-Edel RH, Harisa GE, El-Halawany $\mathbf{N}$ and Ghonaim MM (2009): Experimental diabetic nephropathy can be prevented by propolis: Effect on metabolic disturbances and renal oxidative parameters. Pak J. Pharm Sci; 22(2): 205-10.

Allain CC (1974): Cholesterol enzymatic colorimetric method. J.of Clin. Chem., (20): 470.

Ataie-Jafari A, Larijani B, Alavi Majd H, and Tahbaz F (2009): Cholesterol-lowering effect of probiotic yoghurt in comparison with ordinary yoghurt in mildly to moderately hypercholesterolemic subjects. Ann Nutr Metab; 54(1):227.

Bankova V, Christov R, Kujumgiev A, Marcucci MC and Popov S (1995): Chemical composition and antibacterial activity of Brazilian propolis. Zeitschr für Naturforsch; 50 (3-4):167-72.

Baroutkoub A, Mehdi RZ, Beglarian R, Hassan J, Zahra S, Mohammad MS and Hadis EM (2010): Effects of probiotic yoghurt consumption on the serum cholesterol levels in hypercholestromic cases in Shiraz, Southern Iran. Sc Res and Essays; 5(16): 2206-9.

Batta AK, Salen G, Arora R, Shefer S, Batta $M$ and Perseon I (1990): Side chain conjugation prevents bacterial 7-dehydroxylation of bile acids. J. Biol Chem; 265:10925-8.

Begley M, Hill C and Gahan C (2006): Bile Salt Hydrolase Activity in Probiotics. Appl Environ Micobiol; 72(3): 1729-38.

Bhadauria M (2011): Propolis Prevents Hepatorenal Injury Induced by Chronic Exposure to Carbon
Tetrachloride. Evid Based Complem Alternat Med.

Bijyoet AGA, Kroos MA, Pieper FR, De Boer HA, Reuser AJJ, Vander Ploeg AT and Verbeet MP (1996): Expression of cDNó-encoded human acid $\alpha$-glucosidase in milk of transgenic mice. Biochim Biophys Acta 1996; 1308:93-6.

Bourlioux $P$ and Pochart $P$ (1988): Nutritional and health properties of yoghurt. World Rev J of Nutr Diet; 56: $217-58$.

Bruckert E (2006): Epidemiology of low HDL-cholesterol: results of studies and surveys. Eur Heart J. Suppl; 8:1722.

Cam M, Yavuz O, Guven A, Ercan F, Bukan $N$ and Ustundag $N$ (2003): Protective effects of chronic melatonin treatment against renal injury in streptozotocin- induced diabetic rats. J. Pineal Res; 35:21220.

Campbell JA (1963): Methodology of Protein Evaluation. RAG Nutr. Document R.10 Led. 37. June Meeting, New York.

Cano PG, Aguero G and Perdigon G (2002): Immunological effects of yoghurt addition to a re-nutrition diet in a malnutrition experimental model. J. of Dairy Res.; 69(2):303-16.

Daleprane JB, Da Silva FV, Pacheco A, Rudnicki M, Faine LA, Dörr FA, Ikegaki M, Salazar LA, Ong TP and Abdalla DS (2011): Antiatherogenic and anti-angiogenic activities of polyphenols from propolis. J. Nutr Biochem.

Ejtahed HS, Mohtadi-Nia J, Homayouni-Rad A, Niafar M, Asghari-Jafarabadi M and Mofid V (2011-a): Probiotic yoghurt improves antioxidant status in type 2 diabetic patients. Nutrition j.; 28(5); 539-43. 
Ejtahed HS, Mohtadi-Nia J, Homayouni-Rad A, Niafar $M$, Asghari-Jafarabadi M, Mofid V and Akbarian-Moghari A (2011-b): Effect of probiotic yoghurt containing Lactobacillus acidophilus and Bifidobacterium lactis on lipid profile in individuals with type 2 diabetes mellitus. J. Dairy Sci; 94(7): 3288-94.

El-Kott AF and Owayss AA (2008): Protective Effects of Propolis Against the Amitraz hepatotoxicity in Mice. J Pharmacol Toxicol; 3 (5): 402-8.

El-Sayed SM, Abo-Salem OM, Aly HA and Mansour AM (2009): Potential antidiabetic and hypolipidemic effects of propolis extract in streptozotocininduced diabetic rats. Pak J. Pharm Sci; 22(2):168-74.

Friedewald WT (1972): Determination of HDL. Clin. Chem., 18:499.

Giugliano D, Ceriello A and Esposito $\mathrm{K}$ (2008): Glucose metabolism and hyperglycemia. Am J. Clin Nutr; 87(1): 217S-22S.

Gordon $T$ and Amer $M$ (1977): Determination of HDL. J. of Med., 62:707.

Hegseted DM, Mills RC, Evehjem CA and Hart EB (1941): Choline in nutrition of chiks. J. of Biol. Chem., 138:459-70.

Kajimoto Y and Kaneto H (2004): Role of oxidative stress in pancreatic betacell dysfunction. Ann NY Acad Sci J.; 1011; 168-76.

Kiessling G, Schneider $J$ and Jahries G (2002): Long-term consumption of fermented dairy products over 6 months increases HDL cholesterol. Eur J. Clin Nutr; 56(9):843-9.

Kim YM, Jeong YK, Wang MH, Lee WY and Rhee HI (2005): Inhibitory effect of pine extract on $\alpha$-glucosidase activity and postprandial hyperglycemia. Nutrition; $21: 756-61$
Kolankaya D, Selmanoglu G, Sorkun K and Salih $B$ (2002): Protective effects of Turkish propolis on alcohol-induced serum lipid changes and liver injury in male rats. Food Chem; 78(2):213-7.

Krishnakumar K, Augusti KT and Vijayammal PL (1999): Hypoglycaemic and Antioxidant activity of Salacia ablonga wall. Extract in streptozotocin induced diabetic rats. Ind $\mathrm{J}$ Physiol Pharmacol; 43 (3): 510-4.

Kwiterovich PO (2000): The metabolic pathways of high-density lipoprotein, low-density lipoprotein, and triglycerides: a current review. Americ J. Cardiol; 86 (12A): 5L-10L.

Lee $R$ and Nieman $D$ (1996): Nutritional Assessment. $2^{\text {nd }}$ Ed., Mosby, Missouri, USA.

Lee SH and De Boer HA 1994): Production of biochemical proteins in the milk of transgenic dairy cows: the state of art. J. Control release; 29:21321.

Liu CF, Lin CH, Lin CC, Lin YH, Chen CF, Lin CK and Lin SC (2004): Antioxidative natural product protect against econazole-induced liver injuries. Toxicol; 196(1-2):87-93.

Marcucci MC, De Camargo FA and Lopes CMA (1996): Identification of amino acids in Brazilian propolis. $\mathrm{Z}$ Naturforsch; 51: 11-4.

Matsui T, Ebuchi S, Fujise T, Abesundara KJ, Doi S, Yamada $\mathrm{H}$ and Matsumoto $K$ (2004): Strong antihyperglycemic effects of watersoluble fraction of Brazilian propolis and its bioactive constituent, 3, 4, 5,tri-O- caffeoxylquinic acid. Biol Pharm Bull; 27(11):1797-803.

Mercury F, Quagliaro $L$ and Ceriello A (2000): Oxidative stress evaluation in 
diabetes. Diabetes Technol ther; 2:589-600.

Oberley, LW (1988): Free radicals and diabetes. Free Radic Biol Med; 5(2): 113-24.

Pan D and Zhang D (2008): Function and Safety assessment of Lactococus Lactic. Susp Lactic LB 12 As Potential Probiotic Strain. Afri J Biotechn; 7(22):4037-44.

Ramchandran LA and Shah NP (2008): Proteolytic profiles and angiotensin-I converting enzyme and alphaglucosidase inhibitory activities of selected lactic acid bacteria. J. Food Sci; 73 (2): M75-M81.

Roos TU, Heiss EH, Schwaiberger AV, Schachner D, Sroka IM, Oberan T, Vollmar AM and Dirsch V.M (2011): Caffeic Acid Phenethyl Ester Inhibits PDGF-Induced Proliferation of Vascular Smooth Muscle Cells via Activation of p38 MAPK, HIF-1 $\alpha$, and Heme Oxygenase-1. J. Nat Prod; 74(3):352-6.

Rosenson RS, Otvos JD and Freedman DS (2002): Relations of lipoprotein subclass levels and low-density lipoprotein size to progression of coronary artery disease in the Pravastatin Limitation of Atherosclerosis in the Coronary Arteries (PLAC-I) Trial. Am J. Cardiol; 90:89-94.

Sadrzadeh-Yeganeh H, Elmadfa I, Djazayery A, Jalali M, Heshmat R and Chamary M (2010): The effects of probiotic and conventional yoghurt on lipid profile in women. Br J. Nutr; 103(12):1778-83.

Shori AB and Baba AS (2011): Antioxidant activity and inhibition of key enzymes linked to type-2 diabetes and hypertension by Azadirachta indica-yoghurt. J. Saudi Chem Soc.
Shori AB and Baba AS (2011): Comparative antioxidant activity, proteolysis and in vitro $\alpha$-amylase and $\alpha$-glucosidase inhibition of Allium sativum-yoghurts made from cow and camel milk. J. Saudi Chem Soci.

Simin N and Woel-Kyu H (2000): Immunologic effects of yoghurt. Am J. Clin Nutr; 71(4): 861-72.

SPSS (2008): Statistical Package for Social Science, Computer Software, IBM, SPSS Ver. 16.0 in 2008., SPSS Company, London, UK.

St-Onge MP, Farnworth ER and Jones P.J (2000): Consumption of fermented and nonfermented dairy products: effects on cholesterol concentrations and metabolism. Am J Clin Nutr.; 71:674-81.

Toth P (2005): The Good Cholesterol" High-Density Lipoprotein". Circulation; 111 (5): e89-e91.

Trinder $P$ (1969): Determination of triglycerides. Ann. Clin. Biochem., 6: $24-7$.

Vitaglione $\mathbf{P}$, Morisco F, Caporaso $\mathbf{N}$ and Fogliano V (2004): Dietary antioxidant compounds and liver health. Critical Rev in Food Sci and Nutr. J.; 44(7-8):575-86.

Yajing LI, Minli C, Hongzhuan $X$ and Fuliang Hu (2012): Effects of Encapsulated Propolis on Blood Glycemic Control, Lipid Metabolism, and Insulin Resistance in Type 2 Diabetes Mellitus Rats. Evid Based Complement Alternat Med.

Yang $H$ and Wright JR (2002): Human beta cells are exceedingly resistant to streptozotocin in vivo. Endocrinol; 143: 2491-5.

Young $D$ and Pestaner $L$ (1975): Determination of triglycerides. Germany. J.of Clin. Chem., 21: 5.

Yu Y, Si Y, Song G, Luo T, Wang J and Qin S (2011): Ethanolic extract of 
propolis promotes reverse cholesterol transport and the expression of ATPbinding cassette transport A1 and G1 in mice. Lipids; 46(9): 805-11.

Zamami Y, Fujiwara H, Hosoda M, Hino H, Hirai K, Okamoto K, Jin
X, Takatori S, Doi-Takaki S and Kawasaki H (2010): Ameliorative effect of propolis on insulin resistance in Otsuka Long-Evans Tokushima Fatty (OLETF) rats. Yakugaku Zasshi J.; 130(6): 833-40. 


\section{تأثير الزبادى المدعم بصمغ العسل على الفئران المصابة بارتفاع سكر الدم}

\section{حسان مظهر البخارى1}

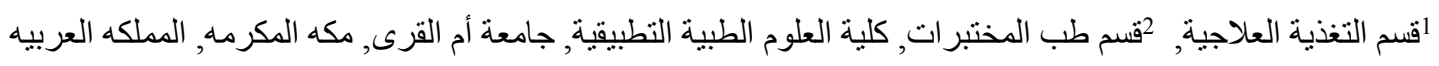

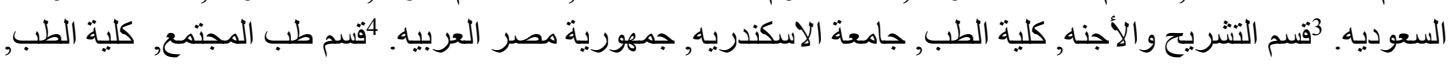

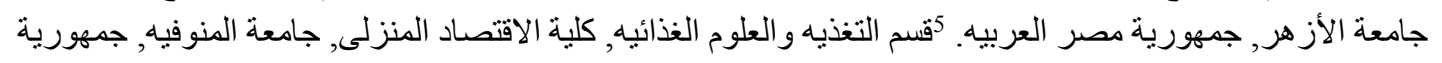
مصر العربيه.

ينصح حاليا بزيادة القيمه الغذائيه للزبادى بإضافة مو اد غنيه بمضادات الأكسده مثل صمغ العسل وهو ماده لزجه

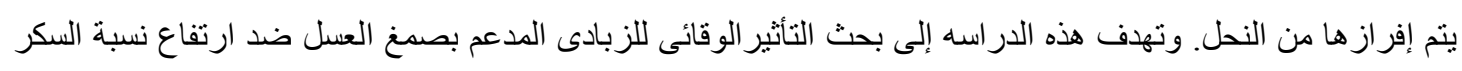
و الاهون في الفئران المصابه بداء السكرى.

وقد أُجريت الدر اسه على 36 فأر حيث تم تقسيمهم إلى مجمو عنين: 18 فأر سليم و 18 مصاب بداء السكرى وتم

قياس نسبه السكر والكوليسترول و الدهون الثلاثيه عالية الكثافه ومنخفضة الكثافه وذات الكثات الكثافه المنخفضه جدا.

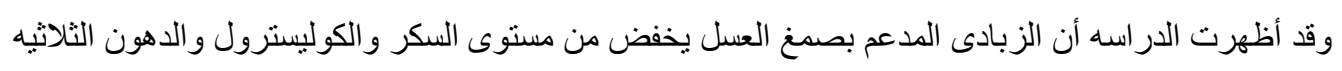

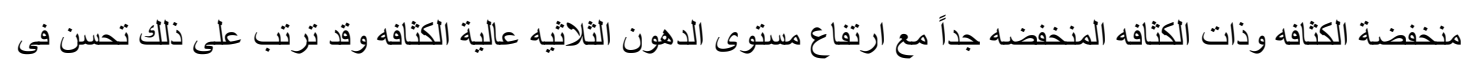

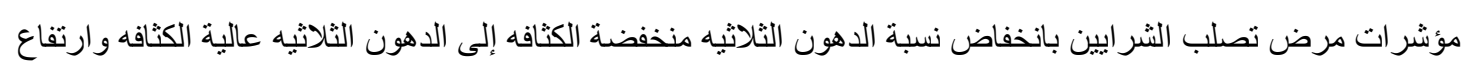

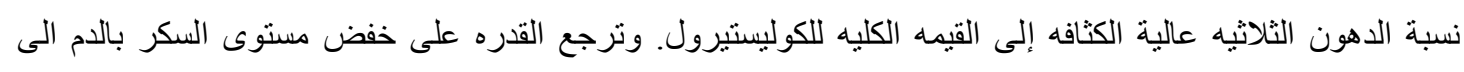

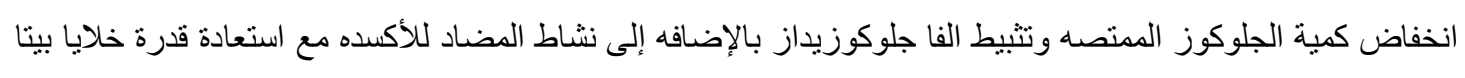

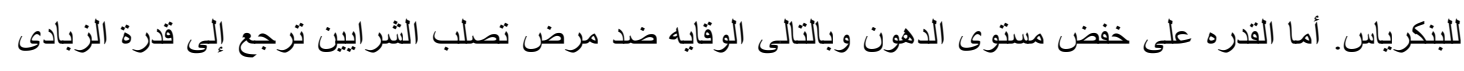

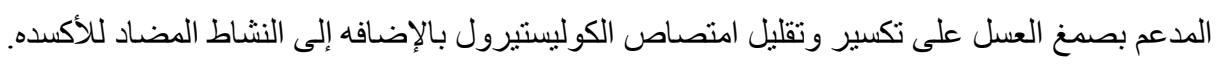

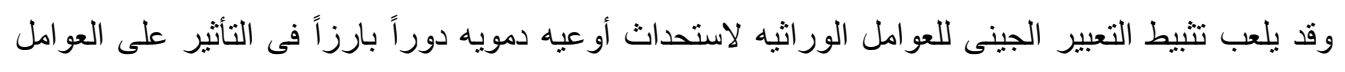
المسببه لمرض تصلب الثر ايين. ونستخلص من ذلك أنه يمكن رفع القيمه الغذائيه للزبادى وتصنيعها واستخدامها فى خفض مستوى السكر و الدهون فى الدم فى حالات الإصابه بداء السكرى. الكلمات المفتاحية: الزبادى - صمغ العسل - مرض السكر - ارتفاع دهون الدم - الكوليستيرول - مضادات الأكسدة. 